\title{
Adoption of active methodologies and their relationship with the life cycle and the qualifications of teaching staff in undergraduate courses in accounting
}

\author{
Leonardo de Rezende Costa Nagib ${ }^{1,2}$ \\ (D) https://orcid.org/0000-0002-9211-5299 \\ Email: leonardonagib@ufu.br \\ Denise Mendes da Silva ${ }^{1}$ \\ (D) https://orcid.org/0000-0002-1490-5148 \\ Email: denise.mendes@ufu.br \\ 1 Universidade Federal de Uberlândia, Faculdade de Ciências Contábeis, Uberlândia, MG, Brazil \\ 2 Universidade Presidente Antônio Carlos, Faculdade de Ciências Contábeis, Uberlândia, MG, Brazil
}

Received on 01.08.2019 - Desk acceptance on 01.30.2019 - $2^{\text {nd }}$ version approved on 05.17.2019 - Ahead of print on 09.12.2019

Associate Editor: Jacqueline Veneroso Alves da Cunha

\begin{abstract}
The objective of this study is to identify and analyze the relationship between the adoption of active methodologies and the teaching life cycle and qualifications of teachers in undergraduate courses in accounting. Thus, a diagnosis is presented regarding the adoption of active methodologies by undergraduate accounting teachers in Brazil, based on the life cycle and qualifications of teaching staff. This study offers a diagnostic tool for teaching staff to support the adoption of active methodologies in the context of teaching accounting, which is affected by the demand for new pedagogical practices to develop soft skills, something that is scarcely addressed in the related literature. Because this adoption depends, in particular, on the teacher's willingness, investigating factors related to teachers enables it to be identified how much they are likely to adopt active methodologies. As a research strategy, an online questionnaire was used, as well as descriptive and variance analysis (ANOVA) to treat the data. The study presents the evidence that the teaching life cycle, pedagogical qualifications, and professional qualifications are positively related to the adoption of active methodologies, while academic qualifications are negatively related to this adoption. Thus, three contributions of this study can be mentioned: institutional, personal, and academic. At the institutional level, it offers decision makers at higher education institutions (HEIs) a tool capable of supporting the implementation of active methodologies, while enabling faculty performance diagnoses to be carried out, identifying the teachers who are more and less likely to adopt active methods. At the personal level, it highlights the need for teachers to keep up to date in terms of new pedagogical practices, in which hard skills and soft skills are developed. At the academic level, it contributes by providing the literature with results on the themes involved.
\end{abstract}

Keywords: accounting, active methodologies, teaching life cycle, teacher qualifications.

Correspondence address

Leonardo de Rezende Costa Nagib

Universidade Federal de Uberlândia, Faculdade de Ciências Contábeis

Avenida João Naves de Ávila, 2121, Bloco 1F - CEP 38400-902

Campus Santa Mônica - Uberlândia - MG - Brazil 


\section{INTRODUCTION}

Active methodologies have emerged in an attempt to build knowledge and develop skills and attitudes in the classroom. For Silva and Scapin (2011), active methodologies can be defined as the set of techniques that transform the learning environment at the same time as modifying the teacher's and student's role, in the search for greater student autonomy in knowledge building. In this case, the teacher takes on the role of advisor, tutor, and mediator in the teaching-learning process.

Huberman (2000) indicates that there is a point in their career when teachers are more likely to adopt new methods, since they feel more familiarized with their activity and are more likely to try new methods in the classroom. From the perspectives indicated by Hernandes, Peleias, and Barbalho (2006), Barbosa and Moura (2013), and Farias and Carvalho (2016), the incorporation of new teaching methods becomes possible when the teacher seeks technical and theoretical knowledge. In addition, for there to be greater assertiveness in determining which active method to use, it is important to link the objectives of the intended technique with the educational objectives outlined for the students' profile, as well as those set out by the teaching institution (Morán, 2013; Nganga, Botinha, Miranda \& Leal, 2016). In other words, the adoption of active methodologies may be affected by the professional stage in which the teacher finds him/herself (teaching life cycle) and by the teacher's qualifications (academic, professional, and pedagogical), and result from incentives from higher education institutions (HEIs), which seek to develop suitable professional competences in students according to their profile and market demand.

Active methodologies are a target of study in various areas of knowledge (Biggs, 1999; Gainor, Bline \& Zheng, 2014; Kane, 2004; McDowall, Jackling \& Natoli, 2015; Morán, 2013). In accounting, the studies are guided by different focuses, such as the experience of applying active methods (Breton, 1999; Carenys, Moya \& Perramon, 2017; Guerra \& Teixeira, 2016; Guimarães, Cittadin, Giassi, Guimarães \& Bristot, 2016; Leal \& Borges, 2016; Oliveira \& Chioratto, 2017; Oliveira, Gomes \& Titton, 2016; Stanley \& Marsden, 2012). Others have aimed to identify which active methods are most adopted by accounting teachers (Nganga et al., 2016). However, studies that relate the adoption of active methodologies with the teaching life cycle and teacher qualifications are rare.
In this context, and considering (i) studies that demonstrate that active methodologies can help students in aspects of improving academic performance and in developing skills and attitudes, (ii) that the adoption of active methodologies by teachers may be associated with the teaching life cycle and/or be influenced by the teacher's qualifications due to the motivations present in each stage of his/her career and the competences developed in each area of training, and (iii) the lack of studies that seek to explain this association and/or influence, notably in the field of undergraduate accounting teaching, which has been recently affected by convergence with the international accounting standards, the following questions arises to guide this study: what is the relationship between the adoption of active methodologies and the life cycle and qualifications of teachers in undergraduate courses in accounting?

Thus, the aim of this study is to identify and analyze the relationship between the adoption of active methodologies and the life cycle and qualifications of teaching staff in undergraduate courses in accounting. Hence, a diagnosis is presented regarding the adoption of active methodologies by teachers in undergraduate accounting courses in Brazil, based on the teaching life cycle and teachers' qualifications. For this, the active methodologies are divided into four categories, in accordance with Leal, Miranda, and Casa Nova (2017c), as presented in section 2.1.

This study is expected to present three forms of contribution: institutional, personal, and academic. As an institutional contribution, the study may provide decision makers at HEIs with a tool for supporting new institutional strategies; that is, based on the desire or need to implement active methodologies in their institutions, managers will have a tool available that is able to diagnose which teacher profile is most likely to adopt active methodologies. The personal contribution of this study relates to the need for teachers to keep up to date on the pedagogical practices indicated to change the classroom environment, placing the student as the main actor in knowledge building, in order to develop skills and attitudes required from future accounting professionals. Finally, the academic contribution involves adding an assessment to the literature of what the adoption of active methodologies is like in undergraduate accounting teaching and how this adoption relates with variables that are intrinsic to the teacher. 


\section{LITERATURE REVIEW AND RESEARCH HYPOTHESES}

\subsection{Active Methodologies}

The role of HEIs lies in equipping citizens with technicaltheoretical knowledge (hard skills) and abilities, behaviors, and attitudes (soft skills). With regards to soft skills, Weber, Finley, Crawford, and Rivera (2009) and Villiers (2010) indicate that these are human characteristics that can be developed, such as communicational, interpersonal, and behavioral skills that, together with the technical abilities, place the student in a favorable position in the labor market.

As a way of turning the classroom into an environment that is conducible to building technical-theoretical knowledge, as well as developing soft skills in students, teaching-learning methods have emerged that outperform the traditional methodology, that is, expository lessons. These include active methodologies, which for Silva and Scapin (2011) are methods in which the teacher is no longer the main party responsible for building knowledge. With this, the student is expected to become more active in the teaching-learning process, seeking to develop hard and soft skills (Villiers, 2010).

From a comprehensive perspective, Leal, Miranda, and Casa Nova (2017b) address methodologies that revolutionize the classroom, which from the authors' viewpoint include: discussed expository lessons; verbalization and observation groups (VGOG); dramatization; films; seminars; debates; storytelling; problem-based learning (PBL); roleplay; the case method; and integrated panels. In addition, in accounting teaching, results can be found relating to the use of the inverted classroom methodology, such as those presented by Oliveira and Chioratto (2017).

Based on this list, Leal et al. (2017c) present a categorization of the active methodologies, based on their characteristics and ways of working with the contents in order to achieve educational objectives. This categorization is used in the elaboration of this study's hypotheses. Table 1 shows the categories, the active methodologies, and the corresponding objectives, as well as reinforcing the concept that active methodologies aim to place the student in an active position with regards to knowledge, moving the teacher into the role of tutor and advisor in the knowledge-building process. Thus, Borges and Alencar (2014) indicate that the teacher's presence in this process is indispensable, since he/she becomes a key actor in the mediation and interaction of the students with the active methods.

\section{Table 1}

Categorization of the active methodologies

\begin{tabular}{|c|c|c|}
\hline Categories & Active methodologies & Objectives \\
\hline \multirow{4}{*}{ Use of art } & $\begin{array}{l}\text { Storytelling (Lelic, 2001; Marques, Miranda \& } \\
\text { Mamede, 2017; Tavares \& Ribeiro, 2016) }\end{array}$ & $\begin{array}{l}\text { This methodology is able to capture the student's attention using real or } \\
\text { fictitious stories. It can stimulate creativity, since the student may be the } \\
\text { storyteller. }\end{array}$ \\
\hline & $\begin{array}{l}\text { Dramatization (Medeiros, Miranda \& Miranda, } \\
\text { 2009; Medeiros \& Queiroz, 2017) }\end{array}$ & $\begin{array}{l}\text { This works with the students' creativity, placing them in active situations } \\
\text { in the creation of scripts and roleplaying. It develops the ability to } \\
\text { improvise and memorize. }\end{array}$ \\
\hline & Roleplay (Koudela, 2011; Souza, 2006) & $\begin{array}{l}\text { This seeks to create a simulated environment in which the students' } \\
\text { take on roles (roleplaying) outside of their reality. This technique aims to } \\
\text { stimulate creativity, interaction, and socialization, as well as developing } \\
\text { memorization. }\end{array}$ \\
\hline & $\begin{array}{l}\text { Films (Colauto, Silva, Tonin \& Martins, } \\
\text { 2017; Leal, Miranda \& Casa Nova, 2017c; } \\
\text { Mendonça \& Guimarães, 2008) }\end{array}$ & $\begin{array}{l}\text { This methodology seeks to bring to the classroom a representation of } \\
\text { the studied theory using firms in which real or fictitious situations are } \\
\text { indicated, which make what has been studied in the classroom tangible. }\end{array}$ \\
\hline \multirow{3}{*}{$\begin{array}{l}\text { Exhibition-based } \\
\text { strategies }\end{array}$} & $\begin{array}{l}\text { Discussed expository lessons (Coimbra, 2017; } \\
\text { Leal \& Cornacchione, 2006; Lopes, 2003) }\end{array}$ & $\begin{array}{l}\text { This is an evolution of the traditional classroom, in which knowledge is } \\
\text { created by the teacher and the student through constant dialogue, even } \\
\text { though the teacher is responsible for explaining the content. }\end{array}$ \\
\hline & $\begin{array}{l}\text { Seminars (Leal, Medeiros, \& Ferreira, 2017a; } \\
\text { Mazzioni, 2013; Veiga, 2003) }\end{array}$ & $\begin{array}{l}\text { This methodology places the student as the main party responsible } \\
\text { for creating knowledge on a particular topic, since it makes him/her } \\
\text { responsible for presenting some content to classmates. }\end{array}$ \\
\hline & $\begin{array}{l}\text { Inverted classroom (Bergmann \& Sams, 2016; } \\
\text { Valente, 2014) }\end{array}$ & $\begin{array}{l}\text { This method is able to bring the use of technology into the academic } \\
\text { environment. For this, the classroom is transformed into an environment } \\
\text { for resolving exercises and answering questions. Outside the classroom, } \\
\text { via the internet, the student will watch the video lessons made available } \\
\text { that include the theoretical content. }\end{array}$ \\
\hline
\end{tabular}


Table 1

Cont.

\begin{tabular}{|c|c|c|}
\hline Categories & Active methodologies & Objectives \\
\hline \multirow{2}{*}{ Problematization } & $\begin{array}{l}\text { Problem-based learning (Hadgraft \& Holecek, } \\
\text { 1995; Piolla, 2001; Soares, Botinha, Casa } \\
\text { Nova, Soares \& Bulaon, 2017) }\end{array}$ & $\begin{array}{l}\text { This seeks to work on logical reasoning and critical thinking to find } \\
\text { the solution to a problem proposed by the teacher. It is a technique } \\
\text { that enables the solution to be presented over the semesters, that is, in } \\
\text { increasing and phased knowledge building. }\end{array}$ \\
\hline & $\begin{array}{l}\text { Case method } \\
\text { (Curado, 2011; Graham, 2010; Ikeda, Veludo- } \\
\text { de-Oliveira \& Campomar, 2005; Leal et al., } \\
\text { 2017a; Menezes, 2009) }\end{array}$ & $\begin{array}{l}\text { This method aims to bring the student closer to real or fictitious cases, } \\
\text { thus creating an environment for discussing the issue depicted by the } \\
\text { topic. }\end{array}$ \\
\hline \multirow{3}{*}{ Dynamics } & $\begin{array}{l}\text { Verbalization and observation group } \\
\text { (Bordenave, 2002; Masetto, 2003; Gil, 2006; } \\
\text { Oliveira \& Campos, 2017) }\end{array}$ & $\begin{array}{l}\text { This is a group dynamics methodology that seeks to divide the } \\
\text { students into two groups. The verbalization group is responsible for the } \\
\text { discussion of the topic proposed by the teacher. The observer group } \\
\text { makes notes on what has been discussed. }\end{array}$ \\
\hline & Integrated panel (Camargo \& Oliveira, 2017) & $\begin{array}{l}\text { This proposes the promotion of interactive learning, as well as being a } \\
\text { way of stimulating the student to work in a group. }\end{array}$ \\
\hline & $\begin{array}{l}\text { Debates (Bordenave \& Pereira, 2002; Masetto, } \\
\text { 2003; Gil, 2006; Castanho, 2012; Moura, } \\
\text { Pereira \& Souza, 2017) }\end{array}$ & $\begin{array}{l}\text { This methodology is responsible for creating a controlled discussion } \\
\text { environment, in which the students are divided into groups according to } \\
\text { their position on a topic. It develops exposure to ideas and respect for } \\
\text { different opinions among the students. }\end{array}$ \\
\hline
\end{tabular}

Source: Elaborated by the authors based on Leal et al. (2017C).

For Kane (2004), although the use of active methodologies is attractive for classrooms and develops non-technical skills in students, it should be considered that the success of implementing any active methodology is linked to the dialectical relationship between the method and the teacher; that is, for the application to provide the effective educational results envisioned, the teacher must be willing to apply an active method, know the group, and analyze what the best moment is for its adoption.

In support of this view, Oliveira and Chioratto (2017) warn that the adoption of active methodologies can be complex and that no matter how well the teacher develops the application, the students must also be willing to use such methods. Thus, for the use of active methodologies to be successful, besides the teacher-related factors (knowledge of the method, willingness to apply it, defining the moment to apply it), those linked to the students (willingness to study using a new methodology) can have an impact on the results achieved. Added to this are the findings of McDowall et al. (2015), who state that the students' vocational interests can influence the learning methods.

In turn, Leal and Borges (2016) sought to study, based on the perception of teachers in undergraduate courses in accounting, which teaching strategies generate the most effectiveness. So, they carried out a study of teachers in undergraduate accounting courses in subjects focused on management accounting and concluded that, according to the students investigated, the most significant and effective strategies are seminars, directed study, and expository lessons. This suggests that the students investigated prefer active methodologies based on exhibition; that is, they present more familiarity with active strategies related to the traditional expository method.

From the teachers' viewpoint, for the same discipline, but in different institutions in Minas Gerais, according to Nganga et al. (2016) the results denote that there is no difference in learning effectiveness between a group of students subjected to the active methodology and a group that is subject to the traditional expository lesson. This result reveals that the adoption of active methodologies may be a differential for some disciplines, but for others it is not. In addition, there is the possibility of mixing the use of active methods with traditional expository lessons [for example, in the studies by Breton (1999) and Stanley and Marsden (2012)].

For Breton (1999), the efficiency of active methods can be measured by comparing two populations. This author compared two accounting theory groups, one using the traditional method and the other the PBL method. The researcher concluded that the group using the active method performed statistically better that the one using the traditional method. Hence, there is evidence that active methodologies, when well applied, can lead to enhanced performance.

Along the same lines, Stanley and Marsden (2012) investigated the application of PBL in undergraduate accounting courses and concluded that this methodology is capable of promoting the development of questioning skills, teamwork, and problem solving. The researchers highlight that the promotion of skills geared towards 
questioning is rare in accounting, so active methodologies, especially PBL, can act to drive a change in the student's profile, creating an attractive professional in relation to social and market demands.

In contrast, Carenys et al. (2017) addressed the use of games in the academic environment as a teaching methodology, with the aim of understanding the behavior of attributes such as student motivation and performance. These researchers defend the inclusion of games in the university environment, since a significant increase in motivation and performance was observed. Thus, this result supports the use of active methodologies in the classroom, since besides performance, it is possible to promote an improvement in behavioral indicators, such as motivation and attendance.

In addition, Masetto (2003) indicates that the adoption of active methods can promote creativity, learning, experience, knowledge, attitudes, and values in the student that add to the accounting professional's technical skills. Thus, the adoption of active methodologies can change the trained professional's profile, in that he/she develops, besides technical skills, behavioral abilities. In this sense, Perini, Fonseca, and Gnap (2018) indicate that the adoption of active methodologies in the area of business favors the formation of a more desirable professional in the labor market. However, the researchers indicate that, in this area of knowledge, teachers are behind in terms of applying active methods.

Thus, teachers may be considered active with regards to their choice and application of active methodologies. However, for the application to be successful, the teacher must seek to understand how active methods can be implemented in the subjects they teach, how these methods can provide a path towards achieving educational objectives, and which skills and attitudes a particular method can develop in the student. The teacher should acquire knowledge regarding the use of active methodologies by means of his/her own evolution in the career (teaching life cycle) and through training.

\subsection{Teaching Life Cycle}

The teaching life cycle represents the structuring of the teaching career in phases that cover time intervals and different behaviors (Huberman, 2000). Therefore, the study of the teaching life cycle is understood as the investigation of phases of the teacher's career, covering its beginning up to exiting the career.
As indicated by Huberman (2000) and Cardoso (2017), initially the studies on this topic covered only the first years of the teacher's career, and did not investigate the events that led to behavioral changes during professional development. In turn, Fole and Nascimento (2008) suggest that it is important to understand how the teacher traverses all the stages of the professional life cycle.

Huberman (2000) structured a teaching life cycle model in which the teacher can cover up to five stages, with individual behaviors being fundamental elements for progression in this career. Other authors, for example Moita (2000) and Gonçalves (2000), present structures for the teaching life cycle, but they are equivalent models to the one set out by Huberman (2000).

The findings of Gonçalves (2000), Huberman (2000), and Moita (2000) converge when they indicate that fitting into each stage of the life cycle may consider, besides time in the career, the individual behavioral aspects of each teacher. Another similarity between the models was the international proposal; that is, they were not developed based on the reality of teachers in Brazil.

In the field of accounting, the studies by Araújo, Lima, Oliveira, and Miranda (2015) and Cardoso (2017) stand out, who addressed the teaching life cycle topic in the Brazilian context, using the model proposed by Huberman (2000), as they considered the seminal structure regarding the determination of each stage. Cardoso (2017) concludes that the topic is still limited and features few results in the literature, and he notes that when analyzing the accounting context the findings are even scarcer.

It should be mentioned that there is no teaching life cycle model mapped out for the reality of accounting teachers in Brazil, but in the literature there is evidence that the model proposed by Huberman (2000) may be applicable to the research in the area of accounting, since as a limitation of the research that addresses this topic, there is the impossibility of using a model based on the behavior of Brazilian teachers. Thus, one limitation of this study lies in the inexistence of a teaching life cycle model developed for the area of accounting.

Moreover, the time the model from Huberman (2000) was created may not reflect the evolutions in the teacher's professional behavior. The model defined by Huberman (2000) relates time in the career with the behavior developed by the teacher to define the stages of the teaching life cycle. The researcher indicates that the teaching career can be covered by five stages. Figure 1 schematizes the teaching life cycle model from Huberman (2000). 


\begin{tabular}{|l|c|}
\hline Years of the career & Phases of the career \\
\hline $1-3$ & \\
\hline $4-6$ & Diversification \\
\hline $25-35$ & Serenity \\
\hline
\end{tabular}

Figure 1 Teaching life cycle model from Huberman (2000) Source: Huberman (2000, p. 47).

The teaching life cycle model presented by Huberman (2000) shows that, in the first years of the career, the teacher is in the entry phase. For the author, it is in this phase that the teacher is enthusiastic about carrying out the profession and this high enthusiasm can lead him/ her to a reality shock.

In this sense, Isaia and Bolzan (2010) indicate that a reality shock is defined as frustration that what is expected does not occur. According to the authors, this frustration may be the result of entering into the teaching career due to an opportunity and not any previous desire, or through insecurity, which is aggravated by the centralization of the content due to fear of questioning or pedagogical inadequacy.

The second phase of the teaching life cycle is called stabilization. In this period, the teacher is more confident with regards to teaching, if compared with the entry phase, and begins to assume a position and take decisions regarding his/her career (Cardoso, 2017).

Then there is the third phase of the life cycle, which Huberman (2000) defines as the longest stage, and which can cover various teacher behaviors. It is in this phase that the teacher knows the profession well, knows what position to assume regarding his/her decisions, and is initially open to experimenting with new possibilities. Thus, Araújo et al. (2015) indicate that, at this point, the teacher faces the experimentation period, and aims to innovate in class, with diversified materials and new class formats. Complementarily, Huberman (2000, p.42) states that, in this stage, the teacher is "more committed to the pedagogical team". After the initial periods of this stage, the teacher may remain motivated to diversify or begin to question how many possibilities there still are to add to his/her teaching career.

The fourth stage of the teaching life cycle presents a ramification between serenity and conservatism. The serenity dimension is the result of a teacher who has traversed the third phase under the diversification aspect, but which, according to Huberman (2000), indicates the generational gap between teacher and student, makes the teacher remain more serene, distancing him/herself from the students, and, consequently, makes him/her willing to innovate and seek new methods. In contrast, a teacher who has traversed the questioning phase of the previous stage at this point experiences conservatism, in which he/she confirms a certain distancing from the teaching career, even becoming nostalgic regarding his/ her consummated achievements.

Finally, Huberman (2000) indicates that the end of the teaching career can be understood by divestment and reflection on the path taken over the course of the career. Thus, he argues that the career may be exited happily with a feeling of achievement or based on a feeling of serenity and bitterness.

In light of the above, the later in the profession, that is, the more the teacher advances in the life cycle stages, the greater the accumulation of experiences and learning, as well as the development itself required by the career. Thus, it is deduced that there may be a relationship between the adoption of active methodologies and the stage of the teaching life cycle, in that the teacher adopts active methods more as he/she advances in the stages of the teaching life cycle. This leads to the study's first hypothesis: 
$\mathrm{H}_{1}$ : the more advanced the teacher's life cycle stage is, the greater his/her adoption will be of the categories of active methodologies.

In addition, in this study it is considered that the adoption of active methodologies by teachers in undergraduate accounting courses may also be related with the teachers' qualifications.

\subsection{Teacher Qualifications}

The purpose of the university environment is to create and spread knowledge, whether through research or teaching (Ruff, Thibodeau \& Bedard, 2009). One of the factors that contribute to this objective being achieved is the teaching staff working at the teaching institution. From this perspective, Miranda (2011) states that HEIs should have, in their teaching staff, qualified professionals, both for research and for teaching.

With regards to teacher qualifications, according to Miranda (2011), these can be academic, professional, and pedagogical. Each qualification covers a set of variables that define its type. From Table 2, it is possible to identify three types of teaching qualification, the corresponding variables, and the aims of each one.

Table 2

Teacher qualifications

\begin{tabular}{|c|c|c|c|}
\hline Qualification & Definition of the qualification & Variables & Definition of the variable \\
\hline \multirow[b]{2}{*}{ Academic } & \multirow{2}{*}{$\begin{array}{l}\text { Refers to the teacher's preparation for } \\
\text { teaching and carrying out research. }\end{array}$} & Academic qualification & $\begin{array}{l}\text { The teacher's current academic qualification (degree, } \\
\text { specialization, master's, or Ph.D.). }\end{array}$ \\
\hline & & Employment status & $\begin{array}{l}\text { Working hours defined in the contract between the } \\
\text { teacher and the higher education institution ( } 20 \text { hours, } \\
40 \text { hours, paid by the hour, or full-time dedication). }\end{array}$ \\
\hline \multirow{3}{*}{ Professional } & \multirow{3}{*}{$\begin{array}{l}\text { Refers to the teacher's experience, } \\
\text { both in the academic career and in } \\
\text { the labor market. }\end{array}$} & Academic experience & Years of experience that the teacher has in teaching. \\
\hline & & Professional experience & $\begin{array}{l}\text { Experience as a market professional (outside the } \\
\text { academic environment). }\end{array}$ \\
\hline & & $\begin{array}{l}\text { Professional } \\
\text { certifications }\end{array}$ & $\begin{array}{l}\text { Quantity of professional certifications, such as inscription } \\
\text { in the Regional Accounting Council, for example. }\end{array}$ \\
\hline \multirow{2}{*}{ Pedagogical } & \multirow{2}{*}{$\begin{array}{l}\text { Refers to the teacher's pedagogical } \\
\text { training for teaching. }\end{array}$} & $\begin{array}{l}\text { Initial pedagogical } \\
\text { training }\end{array}$ & $\begin{array}{l}\text { Concerns whether the teacher took any pedagogical } \\
\text { training courses/disciplines or not over the course of his/ } \\
\text { her post-graduation. }\end{array}$ \\
\hline & & $\begin{array}{l}\text { Continued pedagogical } \\
\text { training }\end{array}$ & $\begin{array}{c}\text { Concerns whether the teacher has taken any courses } \\
\text { focused on pedagogy after concluding his/her post- } \\
\text { graduation. }\end{array}$ \\
\hline
\end{tabular}

Source: Elaborated by the authors, adapted from Miranda (2011).

Academic qualifications, besides preparing the teacher for carrying out research, keep him/her continually updated, with new ideas and a critical approach (Kachelmeier, 2002). Thus, the adoption of active methodologies is expected to be positively associated with the teacher's academic qualifications; that is, the more academic qualifications the teacher has, the greater his/ her adoption of active methodologies should be.

Regarding employment status, Ferreira (2015) indicates that there are two types at Brazilian universities: full time and part time. For Miranda (2011), teachers working full time are in the best position to get involved in research-related activities. Ferreira (2015, p. 53) explains that teachers working part time "normally also carry out teaching, research, and extension activities, but they are not dedicated to this full time", and may be engaged in activities outside the university. From this perspective, teachers working full time are the ones who most adopt active methodologies, thus reflecting, in a similar way to academic qualifications, a positive relationship. Therefore, the paper also aims to investigate the following second study hypothesis:

$\mathrm{H}_{2}$ : (a) the more academic qualifications the teachers has and (b) the higher his/her employment status at the university, the greater his/her adoption of the categories of active methodologies.

Academic experience, together with professional experience, enables the students to be offered an up-todate view of what is happening in the market, providing parallels between theoretical and practical situations. In addition, whether the teacher has experience in another profession besides teaching can favor the adoption of active methodologies, since attitudes and skills perceived and desired in the professional environment can be worked 
on using these in the classroom. In this sense, teamwork, exposure to and defense of viewpoints, and argument development skills stand out. Thus, in a similar way to academic qualifications, it is judged that the adoption of active methodologies is positively related to teaching experience and professional experience.

The third variable related to professional qualifications is professional certification. For Diehl and Souza (2007), professional certification is the training the accountant carries out in the search for excellence, meaning he/she presents certain "credentials" to the market that enable him/her to carry out a particular activity better. As an example of professional certification, the Certified Public Accountant (CPA) in the United States can be mentioned. In Brazil, there is the National Registry of Independent Auditors (CNAI), the National Registry of Forensic Accountants (CNPC), and inscription in the Regional Accounting Council (CRC).

This variable is expected to be positively related with the adoption of the active methodology categories, since as it involves certification geared towards the labor market, when explaining things the teacher is able to shed light on examples of practical situations that may involve the use of methodologies such as storytelling and the case method. In addition, the use of VGOG may be stimulated with a discussion regarding practical situations experienced by the teacher, leading students to develop and present arguments based on the problematization used by the teacher.

In light of these aspects regarding teachers' professional qualifications, the third study hypothesis is set out:

$\mathrm{H}_{3}$ : the greater the teacher's (a) academic experience, (b) professional experience, and (c) professional certification, the greater his/her adoption of the active methodology categories.
Finally, pedagogical qualifications enable skills for teaching to be discussed. Perazo, Machado, Cruz, and Quintana (2016) investigated the teaching qualifications of accounting teachers and concluded that the number of teachers who have taken complementary courses focusing on the pedagogical area is still low. In addition, Cruz, Quintana, Machado, Czarneski, and Lucas (2017) state that accounting students in Brazil and Portugal define a good teacher as a professional who, besides technical knowledge, presents didactics and can relate the theoretical contents with the practices experienced in the profession. Along the same lines, Rezende and Leal (2013) list the characteristics of accounting teachers that are desired by accounting students. The authors conclude that didactics, creativity, and communication are among the strengths most valued by students. This result is consistent with the findings of Perazo et al. (2016) and Cruz et al. (2017), which strengthens the need for teachers to get pedagogically qualified, since aspects such as didactics, creativity, and the theoretical-practical relationship were remembered by the students.

In light of this, initial and continued pedagogical training is expected to positively affect the adoption of the active methodology categories. This expectation occurs due to the possibility that, during pedagogical training courses, teachers have contact with methods that put the student in an active position in terms of knowledge building. Thus, the fourth study hypothesis is presented:

$\mathrm{H}_{4}$ : the greater the teacher's (a) initial pedagogical training and (b) continued pedagogical training, the greater his/her adoption of the active methodology categories.

For the investigation regarding these hypotheses, we now move on the obtainment, analysis, and discussion of the results.

\section{METHODOLOGICAL PROCEDURES}

This study aims to identify and analyze the relationship between adopting active methodologies and the teaching life cycle and teacher qualifications in undergraduate accounting courses. To achieve this objective, teachers who teach subjects in undergraduate accounting courses in Brazil were studied. Thus, all the inferences made in this study are limited to the sample investigated.

Access to the teachers was made possible by building a database of email addresses that were available from the websites of public and private HEIs in Brazil that offer undergraduate courses in accounting. For those institutions that did not make the professors' email addresses available on their websites, contact was made with the course coordination in order to obtain these data.

The research instrument was a questionnaire consisting of two parts. In the first, the questions were related to the sociodemographic context; that is, the questions sought to characterize the teachers with regards to age, sex, area 
of training, and the variables that compose the teaching life cycle and teacher qualifications. In the second part of the questionnaire, 13 hypothetical situations (scenarios) experienced in the classroom in undergraduate accounting courses were presented, in which the teacher should indicate whether he/she adopts the methodology shown or not, using a score on a scale from 0 to 10 . Scores closer to 0 represented a lower level of use of the methodology and scores close to 10 represented a higher degree of use of the methodology. Each one of the hypothetical situations reflected the active methodologies described in Table 1, with one of them corresponding to the traditional expository lesson.

The first step after building the instrument was to test its reliability using a pre-test. The reliability indicator used was Cronbach's alpha. For Matthiensen (2011), Cronbach's alpha conveys the reliability of an instrument in that it presents, on a scale ranging from 0 to 1 , how much the collection instrument manages to the answer the research problem. The author cited indicates that the closer the reliability index is to 1 , the more reliable the instrument is, that is, the more the data manage to answer the research problem.

Subsequently to carrying out the pre-test, a Cronbach's alpha of 0.833 was obtained, which indicates strong reliability of the instrument. However, improvements in the wording of the questions and a reduction in the size of the questionnaire were indicated by the teachers who took part in the pre-test. Thus, after the adjustments that were considered appropriate, the second pre-test round was carried out, which indicated a reliability index of
0.844, enabling it to be concluded that the instrument was ready to be applied to the population being studied.

The questionnaire was then uploaded onto the Google Forms electronic platform and the link was sent to the teachers of the undergraduate accounting courses in Brazil using their institutional emails. Three requests were sent between the months of March and April of 2018. All in all, 5,400 teachers from public and private HEIs were contacted.

As a data analysis procedure, descriptive statistics were used with the introduction of double-entry tables and analysis of variance (ANOVA). At first, the mean of adoption of active methodologies was calculated free of any possible effect caused by the addition of variables that form pedagogical training. This result was called the reference value.

Subsequently, the mean of adoption was recalculated, introducing the initial pedagogical training variable. The results obtained by this new mean were compared with the aforementioned reference values. Finally, ANOVA was applied to measure how much this mean differs when the analyzed methodology category is changed. An identical procedure was used when substituting the initial pedagogical training variable for continued pedagogical training.

To apply ANOVA, a resampling process was carried out with 2,000 interactions, called bootstrapping. This way the intrinsic prerequisites for carrying out ANOVA were met. Moreover, this study uses the nominal significance level ( $\alpha$ ) of 5\%, that is, a 95\% confidence interval (CI95\%).

\section{ANALYSIS AND DISCUSSION OF THE RESULTS}

\subsection{Sample Characterization}

A total of 456 answers were obtained, of which 15 were considered invalid as they were incomplete. Thus, 441 valid answers were considered for the analyses, which corresponds to a sample of $8.82 \%$ of the population contacted. In Table 3 , it is possible to observe that most of the sample are males with a degree in accounting and Ph.D., who work full time at public teaching institutions, have up to 15 years of professional experience, are not engaged in any other activity alongside teaching, have a professional certification, and have initial and continued pedagogical training. 
Table 3

Sample characterization

\begin{tabular}{|c|c|c|}
\hline Characteristics & Categories & Quantity (\%) \\
\hline \multirow{2}{*}{ Sex } & Female & 39.0 \\
\hline & Male & 61.0 \\
\hline \multirow{4}{*}{ Degree } & Accounting & 81.1 \\
\hline & Business & 10.9 \\
\hline & Economics & 2.4 \\
\hline & Others & 5.6 \\
\hline \multirow{2}{*}{ Administrative category of the higher education institution } & Public & 57.0 \\
\hline & Private & 43.0 \\
\hline \multirow{3}{*}{ Title } & Ph.D. & 48.1 \\
\hline & Master's & 41.7 \\
\hline & Specialization & 10.2 \\
\hline \multirow{4}{*}{ Weekly work type } & Hourly wage earner & 22.6 \\
\hline & 20 hours & 12.2 \\
\hline & 40 hours & 23.0 \\
\hline & Exclusive dedication & 42.2 \\
\hline \multirow{3}{*}{ Professional experience } & Up to 15 years & 63.0 \\
\hline & Between 15 and 30 years & 33.4 \\
\hline & More than 30 years & 3.6 \\
\hline \multirow{2}{*}{ Another professional activity alongside teaching } & No & 59.0 \\
\hline & Yes & 41.0 \\
\hline \multirow{2}{*}{ Professional certification } & No & 43.1 \\
\hline & Yes & 56.9 \\
\hline \multirow{2}{*}{ Initial pedagogical training } & No & 21.0 \\
\hline & Yes & 79.0 \\
\hline \multirow{2}{*}{ Continued pedagogical training } & No & 43.0 \\
\hline & Yes & 57.0 \\
\hline
\end{tabular}

Source: Elaborated by the authors.

\subsection{Diagnosis of the Teaching Life Cycle}

Table 4 presents a diagnosis of the distribution of the teachers investigated with regards to the five phases of the teaching life cycle model, according to Huberman (2000). Based on the results, the entry phase is mostly formed of teachers with a master's title. In fact, this title already allows individuals to teach at public and/or private HEIs, since it aims to train teachers (Comunelo, Espejo, Bernardes \& Lima, 2012). The presence of teachers with a master of business administration (MBA)/specialization in the entry phase highlights that it is possible to begin a teaching career with this qualification alone, especially at private HEIs.

Table 4

Diagnosis of the teaching life cycle

\begin{tabular}{|c|c|c|c|c|}
\hline Life cycle & $\begin{array}{l}\text { Ph.D. } \\
\text { n (\%) }\end{array}$ & $\begin{array}{c}\text { MBA/specialization } \\
\text { n (\%) }\end{array}$ & $\begin{array}{c}\text { Master's } \\
\text { n (\%) }\end{array}$ & $\begin{array}{c}\text { Total per phase } \\
\text { n }\end{array}$ \\
\hline Phase 1 - Entry (years 1-3) & $2(1.1)$ & $8(17.8)$ & $33(15.6)$ & 43 \\
\hline Phase 2 - Stabilization (years 4-6) & $15(8.2)$ & $13(28.9)$ & $37(17.5)$ & 65 \\
\hline Phase 3 - Diversification (years 7-25) & $148(80.4)$ & $22(48.9)$ & $126(59.4)$ & 296 \\
\hline Phase 4 - Serenity (years 25-35) & $15(8.2)$ & $2(4.4)$ & $14(6.6)$ & 31 \\
\hline Phase 5 - Divestment (years 35-40) & $4(2.2)$ & $0(0.0)$ & $2(0.9)$ & 6 \\
\hline Overall total & $184(100.0)$ & $45(100.0)$ & $212(100.0)$ & 441 \\
\hline
\end{tabular}

Source: Elaborated by the authors. 
In general, it is perceived that the teachers are concentrated in the third phase of the teaching life cycle, given that this phase is the longest, according to the model from Huberman (2000). According to Table 4, in this phase the highest number of teachers with Ph.D.s are found, leading to the understanding that the teachers may obtain qualifications while carrying out the profession, especially after becoming familiar with the career and deciding the continue in teaching. In addition, it is possible to perceive that few teachers start the profession with a Ph.D. title, thus reinforcing the possibility of accounting teachers obtaining academic titles while already being engaged in teaching.

Also regarding the diagnosis of the accounting teachers in terms of the teaching life cycle, there is evidence that most of those who reach the final stages of the life cycle have a master's or Ph.D. qualification. This finding is linked to the fact that these teachers work at public HEIs, in which, besides teaching, they may be involved in administrative, extension, and research activities.

\subsection{Diagnosis of the Adoption of the Active Methodologies}

The diagnosis regarding the adoption of active methodologies was based on the answers of the participating teachers relating to the scenarios presented in the research instrument that sought to evaluate, on an open scale from 0 to 10 , how much the teachers adopt the methodology portrayed. The mean of individual adoption of each methodology and by category was calculated, as shown in Table 5.

Table 5

Mean of adoption of active methodologies

\begin{tabular}{|c|c|c|}
\hline Categories & Methodologies & Mean of adoption \\
\hline \multirow{5}{*}{ Use of art } & Storytelling & 4.13 \\
\hline & Dramatization & 2.08 \\
\hline & Roleplay & 4.20 \\
\hline & Films & 3.26 \\
\hline & Category mean & 3.42 \\
\hline \multirow{4}{*}{ Exhibition-based strategies } & Discussed expository lesson & 7.37 \\
\hline & Seminars & 4.88 \\
\hline & Inverted classroom & 2.14 \\
\hline & Category mean & 4.80 \\
\hline \multirow{3}{*}{ Problematization } & Problem based learning & 4.44 \\
\hline & Case method & 5.24 \\
\hline & Category mean & 4.84 \\
\hline \multirow{4}{*}{ Dynamics } & Verbalization and observation group & 4.60 \\
\hline & Integrated panel & 3.59 \\
\hline & Debate & 5.87 \\
\hline & Category mean & 5.07 \\
\hline Traditional method & Traditional expository lesson & 5.43 \\
\hline
\end{tabular}

Source: Elaborated by the authors.

In Table 5, it can be observed that the adoption of the active methodology categories by teachers in undergraduate accounting courses in Brazil is still low, especially when it involves techniques such as films, dramatization, storytelling, and roleplay, which are methodologies that compose the use of art category. In addition, it is possible to perceive that the traditional expository lesson is, on average, one of strategies that is most adopted by the teachers studied, and it can thus be concluded that active methods are used alongside the traditional method. This reinforces the findings of Oliveira and Chioratto (2017), who mention that active methodologies should be used complementarily to the traditional model and not as a complete substitution of this.

\subsection{Adoption of Active Methodologies and Teaching Life Cycle}

Table 6 presents the means of adoption of the active methodology categories in relation to the stages of the teaching life cycle, according to the model from Huberman (2000). 
Table 6

Active methodologies and teaching life cycle

\begin{tabular}{lccccc}
\hline Phases of the life cycle & Use of art & Exhibition-based strategies & Problematization & Dynamics & Expository lesson \\
\hline Reference value & 3.42 & 4.80 & 4.84 & 5.07 & 5.43 \\
\hline Phase 1 & 2.72 & 4.41 & 4.75 & 4.22 & 5.93 \\
\hline Phase 2 & 4.18 & 5.17 & 4.41 & 4.64 & 4.34 \\
\hline Phase 3 & 3.26 & 4.70 & 5.43 & 5.11 & 6.32 \\
\hline Phase 4 & 3.72 & 5.16 & 6.37 & 0.15 & 4.00 \\
\hline Phase 5 & 6.27 & 6.32 & $0.042^{*}$ & $0.023^{*}$ \\
\hline ANOVA (p-value) & $0.010^{*}$ & $0.037^{*}$ & & 0.078 \\
\hline
\end{tabular}

ANOVA = analysis of variance.

* = significant at a nominal significance level of 0.05.

Source: Elaborated by the authors.

The results shown in Table 6 indicate that, in the initial stages of the career, the teacher tends to adopt active methods less, if compared with the results based on the second phase of the teaching life cycle. It is shown that for all the active methodology categories the teacher tends to adopt more active methods as he/she consolidates his/her position in the career, that is, as he/she advances in terms of time in the career. This result leads to the possibility of the accounting teacher training pedagogically while already teaching. Aligned with this is the possibility of the teacher adopting active methods more as he/she traverses the teaching life cycle, due to the accumulation of experiences obtained and tested over the course of the profession.

Table 6 also shows the ANOVA result, which indicates the presence of different means for each category of active methodologies analyzed. At a 95\% confidence interval, the adoption of active methodologies is positively related with the teaching life cycle, since for all the categories analyzed, the more the professor advances in the life cycle, the more methods he/she adopts. These results reinforce the idea of the traditional expository lesson not being totally substituted, but rather being used together with the active methods, thus supporting the findings of Cardoso (2017) and Oliveira and Chioratto (2017); that is, active methodologies are complementary instruments and cannot be considered as solutions for all the challenges of higher education.

From the results laid out, hypothesis $\mathrm{H}_{1}$ cannot be rejected; in other words, it can be concluded for the sample investigated that the adoption of the active methodology categories is positively related to the teaching life cycle, in that the more the teacher advances in the life cycle, the greater his/her adoption will be.

\subsection{Adoption of Active Methods and Academic Qualifications}

With regards to the relationship between the adoption of active methodologies and academic qualifications, the variables analyzed are academic titles and employment status. The results are shown in Table 7.

Table 7

Active methodologies and academic qualifications

\begin{tabular}{|c|c|c|c|c|c|c|}
\hline \multicolumn{2}{|c|}{ Academic qualifications } & \multirow{2}{*}{$\begin{array}{c}\text { Use of art } \\
3.42\end{array}$} & \multirow{2}{*}{$\begin{array}{c}\text { Exhibition-based strategies } \\
4.80\end{array}$} & \multirow{2}{*}{$\begin{array}{c}\text { Problematization } \\
4.84 \\
\end{array}$} & \multirow{2}{*}{$\begin{array}{c}\text { Dynamics } \\
5.07\end{array}$} & \multirow{2}{*}{$\begin{array}{c}\text { Expository lesson } \\
5.43\end{array}$} \\
\hline \multirow{5}{*}{ Title } & Reference value & & & & & \\
\hline & Ph.D. & 3.02 & 4.66 & 4.79 & 4.19 & 4.49 \\
\hline & Master's & 3.57 & 4.82 & 5.15 & 4.55 & 5.24 \\
\hline & MBA/specialization & 4.34 & 5.23 & 5.84 & 5.08 & 5.86 \\
\hline & ANOVA (p-value) & $0.005^{*}$ & $0.001 *$ & $0.049 *$ & $0.044^{*}$ & $0.008^{*}$ \\
\hline \multirow{5}{*}{$\begin{array}{l}\text { Employment } \\
\text { status }\end{array}$} & Exclusive dedication & 2.92 & 4.48 & 4.60 & 4.03 & 4.79 \\
\hline & Hourly wage earner & 3.55 & 4.85 & 5.19 & 4.37 & 4.99 \\
\hline & 20 hours a week & 3.93 & 5.11 & 5.32 & 4.85 & 5.57 \\
\hline & 40 hours a week & 3.93 & 5.16 & 5.67 & 5.11 & 5.76 \\
\hline & ANOVA (p-value) & $0.004^{*}$ & $0.014^{*}$ & $0.010^{*}$ & $0.010^{*}$ & $0.027^{*}$ \\
\hline
\end{tabular}

ANOVA = analysis of variance.

* = significant at a nominal significance level of 0.05.

Source: Elaborated by the authors. 
For the academic title variable, Table 7 shows a result that diverges from the one expected by research hypothesis $\mathrm{H}_{2}$ (a), since professors with a Ph.D. present less adoption of the active methodology categories. In other words, the results indicate that there is a relationship between the adoption of active methodologies and the teacher's academic title; however, this relationship is not positive.

For Comunelo et al. (2012), stricto sensu postgraduation courses are geared towards teacher training, therefore for the authors teachers with master's and Ph.D. titles have greater pedagogical knowledge for teaching. In addition, Perazo et al. (2016) highlight the importance of post-graduation programs in aligning theoretical knowledge with teaching practices.

In opposition to Comunelo et al. (2012) and Perazo et al. (2016), it is possible to infer, for the sample studied, that the relationship between the adoption of the active methodology categories and the teacher's academic title is negative, since the elements investigated indicate that the higher the title, the less the teacher tends to adopt active methods. This may be related with the career possibilities Ph.D. holders may be involved with, such as focusing on research. In addition, this result may be linked with the non-promotion by post-graduation programs of pedagogical training for teachers, thus forming professionals focused on carrying out research activities, as explained by Cornachione (2007) and Andere and Araújo (2008).

Analyzing the employment status variable (Table 7), a similar behavior is shown to that perceived when the teacher's academic title is analyzed. The results regarding these two variables (title and employment status) are aligned, given that the teachers working full time mostly have Ph.D.s.

Based on Table 7, it is verified that there is a relationship between the adoption of the active methodology categories and employment status, but this relationship is negative; that is, a greater number of hours dedicated to teaching does not linearly increase the teacher's adoption of active methods. Thus, it is possible to conclude that the more time dedicated to teaching, the lower the adoption of active methodologies, thus rejecting hypothesis $\mathrm{H}_{2}(\mathrm{~b})$. In other words, it is possible to conclude that for this study sample the adoption of the active methodology categories is negatively related to the teacher's academic qualifications, since those teachers with a higher academic qualification are not those who adopt active methods the most. This result presents a new position with regards to that set out by Miranda (2011). Miranda indicated that because teachers with Ph.D.s had undergone all the pedagogical training aligned with classroom experience, they may exhibit more confidence in using new techniques/methods in the classroom.

\subsection{Adoption of Active Methodologies and Professional Qualifications}

The results on the relationship between the adoption of the categories of active methodologies and professional qualifications are presented in Table 8.

Table 8

Active methodologies and professional qualifications

\begin{tabular}{|c|c|c|c|c|c|c|}
\hline \multicolumn{2}{|c|}{ Professional qualifications } & \multirow{2}{*}{$\begin{array}{c}\text { Use of art } \\
3.42\end{array}$} & \multirow{2}{*}{$\begin{array}{c}\text { Exhibition-based } \\
\text { strategies }\end{array}$} & \multirow{2}{*}{$\begin{array}{c}\text { Problematization } \\
4.84\end{array}$} & \multirow{2}{*}{$\begin{array}{c}\text { Dynamics } \\
5.07\end{array}$} & \multirow{2}{*}{\begin{tabular}{|c|} 
Expository lesson \\
5.43 \\
\end{tabular}} \\
\hline \multirow{5}{*}{$\begin{array}{l}\text { Academic } \\
\text { experience }\end{array}$} & Reference value & & & & & \\
\hline & Up to 15 years & 3.51 & 4.72 & 5.07 & 4.45 & 5.48 \\
\hline & $\begin{array}{c}>15 \text { up to } 30 \\
\text { years }\end{array}$ & 3.13 & 4.87 & 5.00 & 4.33 & 5.49 \\
\hline & $\begin{array}{c}\text { More than } 30 \\
\text { years }\end{array}$ & 4.58 & 5.60 & 5.85 & 5.80 & 3.92 \\
\hline & ANOVA (p-value) & $0.007^{*}$ & $0.039^{*}$ & $0.023^{*}$ & $0.000^{*}$ & $0.000^{*}$ \\
\hline \multirow{3}{*}{$\begin{array}{l}\text { Professional } \\
\text { experience }\end{array}$} & No & 1.81 & 4.00 & 3.88 & 2.79 & 6.18 \\
\hline & Yes & 3.48 & 4.83 & 5.11 & 4.51 & 5.40 \\
\hline & ANOVA (p-value) & $0.018^{*}$ & $0.010^{*}$ & $0.037^{*}$ & $0.021 *$ & $0.000^{*}$ \\
\hline \multirow{3}{*}{$\begin{array}{l}\text { Professional } \\
\text { certification }\end{array}$} & No & 3.16 & 4.80 & 5.02 & 4.30 & 5.45 \\
\hline & Yes & 3.62 & 4.80 & 5.12 & 4.57 & 5.56 \\
\hline & ANOVA (p-value) & 0.064 & 0.971 & 0.714 & 0.306 & 0.445 \\
\hline
\end{tabular}

ANOVA $=$ analysis of variance.

* = significant at the nominal significance level of 0.05.

Source: Elaborated by the authors. 
The analysis of the relationship proposed from an academic experience perspective indicates the result that the more time (years) the accounting teacher spends in teaching, the greater his/her adoption of active methods. In line with this, the result of the ANOVA leads to the conclusion that the more experienced the teacher, the more he/she introduces active methods to support the traditional method. Complementarily, this result is consistent with the one identified regarding the teaching life cycle, in that the more advanced in the stages of the career, the greater the adoption of active methodologies. The relationship exists and it is positive.

The results in Table 8 also indicate that teachers who have experience in the labor market, that is, in other careers besides teaching (professional experience), adopt active methods more than teachers who do not have such experience. In addition, the ANOVA indicates that this behavior is repeated for all categories of active methodologies, so that it is possible to affirm that teachers with professional experience adopt the traditional expository lesson less, while adding active methods to their teaching.

For the professional certification variable, the ANOVA indicated that there are no differences in the means of adoption of active methodologies between the teachers who have this certification and those who do not. Thus, it is possible to conclude that the adoption of the active methodology categories is not related to the teacher's professional certifications.

In general, in the sample studied, it is shown that there are relationships between academic experience, professional experience, and the adoption of the active methodology categories, thus leading to the nonrejection of hypotheses $\mathrm{H}_{3}(\mathrm{a})$ and (b). In contrast, there is no relationship between the adoption of active methodologies and the teacher's professional certifications, which leads to the rejection of hypothesis $\mathrm{H}_{3}(\mathrm{c})$. This relationship reinforces the findings of Miranda (2011), that the teacher's classroom experience can facilitate the identification of the students' profiles and, as a result, help in the promotion and experimentation of new methods in the classroom. In addition, professional experience can enable the teacher to take market perceptions into the academic environment, thus promoting discussion and problematization. The lack of evidence that professional certification leads to higher means of adoption of active methodologies supports the idea that being a certified professional does not guarantee professional experience in activities and/or processes that may be applicable in the classroom, whether using an active method or not. Thus, this finding reinforces what is suggested by Diehl and Souza (2007), who indicated that professional certification is a criterion of excellence involving experience in the labor market.

\subsection{Adoption of Active Methodologies and Pedagogical Training}

Table 9 presents the results of the relationship between the adoption of the categories of active methodologies and pedagogical training.

Table 9

Active methodologies and pedagogical training

\begin{tabular}{|c|c|c|c|c|c|c|}
\hline \multicolumn{2}{|c|}{ Pedagogical training } & \multirow{2}{*}{$\begin{array}{c}\text { Use of art } \\
3.42 \\
\end{array}$} & \multirow{2}{*}{$\begin{array}{c}\begin{array}{c}\text { Exhibition-based } \\
\text { strategies }\end{array} \\
4.80 \\
\end{array}$} & \multirow{2}{*}{$\begin{array}{c}\text { Problematization } \\
4.84\end{array}$} & \multirow{2}{*}{$\begin{array}{c}\text { Dynamics } \\
5.07\end{array}$} & \multirow{2}{*}{$\begin{array}{c}\text { Expository lesson } \\
5.43 \\
\end{array}$} \\
\hline \multirow{4}{*}{$\begin{array}{l}\text { Initial } \\
\text { pedagogical } \\
\text { training }\end{array}$} & Reference value & & & & & \\
\hline & No & 2.86 & 4.56 & 4.42 & 3.84 & 6.42 \\
\hline & Yes & 3.57 & 4.86 & 5.24 & 5.62 & 5.15 \\
\hline & ANOVA (p-value) & $0.019 *$ & $0.017^{*}$ & $0.008^{*}$ & $0.015^{*}$ & $0.010^{*}$ \\
\hline \multirow{3}{*}{$\begin{array}{l}\text { Continued } \\
\text { pedagogical } \\
\text { training }\end{array}$} & No & 2.66 & 4.38 & 4.51 & 3.66 & 6.31 \\
\hline & Yes & 3.98 & 5.11 & 5.48 & 5.04 & 4.78 \\
\hline & ANOVA (p-value) & $0.000^{*}$ & $0.000^{*}$ & $0.000^{*}$ & $0.000^{*}$ & $0.000^{*}$ \\
\hline
\end{tabular}

ANOVA = analysis of variance.

* = significant at the nominal significance level of 0.05.

Source: Elaborated by the authors.

From analyzing initial pedagogical training, it is evident that, on average, the teachers who took it adopt active methodologies more than those who do not have such training. Complementarily, it is verified that for the teachers who did not take this training, the mean of adoption of the traditional expository lesson is higher than that for the adoption of active methods. Thus, initial pedagogical training is positively related with the adoption of active methodologies, while teachers who take this type of training adopt active methods more and the traditional 
method less. Adding the results of the ANOVA to this, which indicate that the means of adoption are statistically different at a 95\% confidence interval, leads to the nonrejection of hypothesis $\mathrm{H}_{4}(\mathrm{a})$. This result is aligned with the one indicated by Oliveira and Silva (2012), who suggest that pedagogical teacher training should be an intrinsic condition for teaching.

For continued pedagogical training, the results indicated in Table 9 show that the teachers with this training adopt active methodologies more and the traditional method less. Thus, adoption of the active methodology categories is positively related with this training. In support of this result, the ANOVA indicates that the means of adoption of teachers who have taken at least one continued pedagogical course are statistically different from the means of those who have not had such training, reflecting the non-rejection of hypothesis $\mathrm{H}_{4}(\mathrm{~b})$. Thus, it can be concluded that continued pedagogical training is positively related with the adoption of active methodologies, given that the teachers who take this type of training adopt active methods more and the traditional method less.

From the results found in the sample studied, it is concluded that pedagogical training is relevant to the process of implementing active methodologies, since it is shown that teachers who take this type of training may substitute, when necessary, the traditional method for the active methods. Thus, for teachers who seek to implement active methodologies, pedagogical training may provide knowledge and skills that can promote an understanding of such methodologies and how to implement them in the context of undergraduate accounting teaching.

\subsection{Summary of the Conclusions Regarding the Study Hypotheses}

This section aims to summarize the conclusions regarding the study hypotheses. Thus, Table 10 shows which hypothesis was analyzed, the level of the variable studied, and the conclusion obtained via the ANOVA.

Table 10

Conclusions regarding the study hypotheses

\begin{tabular}{lcc}
\hline Study hypothesis & Variable studied & Conclusion - Study hypothesis \\
\hline $\mathrm{H}_{1}$ & 5 phases of the teaching life cycle & Not rejected \\
Teaching life cycle & Academic title & Rejected \\
\hline $\mathrm{H}_{2}(\mathrm{a})$ & Employment status & Rejected \\
Academic qualifications & Academic experience & Not rejected \\
\hline $\mathrm{H}_{2}(\mathrm{~b})$ & Professional experience & Not rejected \\
\hline $\begin{array}{l}\mathrm{H}_{3}(\mathrm{a}) \\
\text { Professional qualifications }\end{array}$ & Professional certification & Rejected \\
\hline $\begin{array}{l}\mathrm{H}_{3}(\mathrm{~b}) \\
\text { Professional qualifications }\end{array}$ & Initial pedagogical training \\
\hline $\begin{array}{l}\mathrm{H}_{3}(\mathrm{c}) \\
\text { Professional qualifications }\end{array}$ & Continued pedagogical training & Not rejected \\
\hline $\mathrm{H}_{4}(\mathrm{a})$ & & Not rejected \\
\hline $\begin{array}{l}\text { Pedagogical training } \\
\text { Pedagogical training }\end{array}$ & & \\
\hline
\end{tabular}

Source: Elaborated by the authors.

In light of the above, according to the results of this research the hypothesis that the more advanced in the teaching life cycle, the more the teacher tends to adopt active methods is not rejected. In contrast, it is rejected that the higher the teacher's academic title and the more time he/she spends teaching, the greater the adoption of active methods.

With regards to professional qualifications, it is concluded that the greater the academic and professional experience, the more the teacher tends to adopt active methods. This conclusion is not valid when professional certification is analyzed.

Finally, the teacher's pedagogical training is related to the adoption of active methods, in that teachers who present some training in this field tend to adopt active methodologies more.

\subsection{Profile of Adoption of Active Methodologies}

Based on the descriptive analysis, it is possible to determine the teacher profiles in the sample studied 
that tend to adopt active methods more and less. This was based on the following variables: (i) sex; (ii) degree; (iii) academic title; (iv) employment status; (v) phases of the teaching life cycle; (vi) professional experience; (vii) professional certification; (viii) pedagogical training; and (ix) administrative category of the HEI where he/ she works.

Among the teachers studied, those with the greatest tendency to adopt active methodologies in undergraduate accounting courses present the following profile: female teachers, with a degree in accounting, a master's title, on a 40-hours a week contract, in the third phase of the teaching life cycle, with professional experience, professional certification, and pedagogical training. In addition, there is a balance in the division of this profile between public and private HEIs.

Finally, the teacher profile that tends to adopt active methods less is essentially made up of male teachers, with a degree in accounting and business, with a Ph.D., earning an hourly wage, spread between the first and third phases of the teaching life cycle, with pedagogical training, with no professional certification, but with professional experience, equally divided between public and private HEIs.

\section{CONCLUSION}

This study aimed to identify and analyze the relationship between the adoption of active methodologies and the teaching life cycle and teacher qualifications in undergraduate accounting courses, based on the creation of a diagnostic tool capable of enabling evaluations regarding the teaching staff of a HEI.

The first conclusion of the study is that the adoption of the active methodology categories is positively related to the teaching life cycle. This result means that, the more the teacher advances in the phases of the teaching life cycle, the greater the adoption of the active methodology categories and the less the use of the traditional method. This conclusion is consistent with the literature's position, since the traditional method is not totally substituted, but rather complemented by the use of active methods. Thus, it can be concluded that the active methodologies are complementary tools and do not totally substitute the traditional expository lesson.

Second, it can be concluded that academic qualifications are negatively related with the adoption of the active methodology categories. This finding reveals that teachers with higher academic titles or who have taught for longer are not those who most adopt active methods.

In general lines, from the professional qualifications perspective, it is possible to conclude that the teacher's academic and professional experiences are positively related with the adoption of active methodologies. Thus, teachers with more experience in the classroom and in the market use active methods more, this increase possibly being related with the qualifications the teacher obtains over the course of his/her career, by taking continued training courses, or based on the change in the profile of students entering HEIs.
The need is reinforced for teachers to train people who are aligned with market prospects. For this, the use of active methods enhances the development of soft skills in the context of accounting, since the accounting profile demanded by the labor market is based on a more communicative professional with analytical and relationship skills, who can multi-task and is able to seek solutions to problems, among other aspects.

Third, the results regarding pedagogical training reveal the importance of the teacher taking courses focused on pedagogical practices, and if the HEI wishes to invest in the application of active methods in the classroom, it should invest primarily in teacher training. Teachers with pedagogical training are able to understand how to adopt the active methodologies and for what type of subject and/or group adoption if suitable, meaning the process is able to achieve the educational objectives proposed by the HEI and by the teacher. In addition, pedagogical training enables the teacher to understand how the active methodologies can develop soft skills, that is, a set of abilities, attitudes, and behaviors demanded by society and by the labor market.

It is important to highlight that the findings of this study are supported by the use of the active methodology categories, thus the categorization proposed by Leal et al. (2017b) is able to convey the reality regarding teachers' behavior, since the assumptions were confirmed or refuted, as explained.

In addition, another key point of this study is its assessment of the teaching life cycle of teachers in undergraduate accounting courses in Brazil. Thus, the relationships investigated in this paper were based on studying teachers, with the life cycle and teacher 
qualifications aspects being necessary to understand the behavior regarding adoption of the active methodology categories in the sample studied; that is, the results cannot be extrapolated to the whole population of undergraduation teachers, especially accounting ones.

This study offers three levels of contributions: institutional, personal, and academic. With regards to the institutional contribution, it is able to provide decision makers at HEIs with a tool that supports new institutional strategies, that is, based on a desire to implement active methodologies in their institutions. The decision makers will have at their disposal a tool that is able to diagnose the institution's teaching staff in relation to the profile determined by this study that tends to adopt active methods more. Thus, through the possibility of carrying out a diagnosis of the teaching staff, this paper is able to contribute to generating strategies for implementing active methodologies and developing teachers, with the aim of training better professionals. It is noted that to enable the adoption of active methodologies, HEIs need to invest in qualifying teachers, especially in pedagogical training.

In addition, the personal contribution of this study relates to the need for teachers to keep up to date regarding pedagogical practices that can change the classroom environment, by making the student the main actor in building knowledge, thus developing soft skills. It is evident that the development of soft skills is of the upmost importance, given that the profiles of students joining HEIs have changed. In addition to this, there is the desire from society and the labor market for students who have the capacity for observation, decision making, communication, problem solving, and time management, among other skills. And correctly implemented active methodologies can help in the development of these soft skills.

This study also contributes to the literature that involves the topic of diagnosing the teaching life cycle of teachers in undergraduate accounting courses in Brazil. Added to this is the diagnosis of the adoption of active methodologies in undergraduate accounting teaching and how this adoption relates with variables that are intrinsic to the teacher. Thus, analyzing the aspects shown from the teacher's perspective adds evidence to the literature on the topic.

There were various limitations encountered during the course of developing the research. First, there was little literature available regarding the life cycle and teacher qualifications topics, especially applied to accounting. Another limitation that warrants mentioning is the applicability of the teaching life cycle model proposed by Huberman (2000). This model was developed for a French reality, applied in another area of knowledge, as well as being lagged in some decades, since the teacher's profile has changed, as indicated by Araújo et al. (2015).

Also regarding the teaching life cycle, a limiting factor is the third phase of the model proposed by Huberman (2000). As it is the longest phase (18 years), some behavioral movement developed by the teacher that affects the rest of his/her career may be lost. In addition, as the data collection was based on a questionnaire, behavioral characteristics that influence the path followed in the teaching life cycle could not be captured. Thus, defining the career stage by only considering the time in teaching using the cut-offs that fit the model from Huberman (2000) represents another limitation.

It also has to be considered that not studying the levels of professional experience and number of initial and continued pedagogical training subjects/courses is another limitation of the research.

Similarly, the questionnaire's construction may present limitations, since in the literature studied no validated collection instruments were identified that could be reapplied in this research. Thus, despite the reliability test presenting statistical significance, it cannot be ignored that a better structure could be obtained.

It should be mentioned that this study is exploratory in nature; that is, it seeks to add the findings obtained here to the literature on the topic. However, the results obtained could clearly be expanded, since the aim is to analyze the behavioral criteria of teachers, by converting the current research into a qualitative-quantitative analysis. Other methods and approaches would thus need to be used for data collection and analysis of the results. 


\section{REFERENCES}

Andere, M. A., \& Araújo, A. M. P. (2008). Aspectos da formação do professor de ensino superior de ciências contábeis: uma análise dos programas de pós-graduação. Revista Contabilidade \& Finanças, 19(48), 91-102.

Araújo, T. S., Lima, F. D. C., de Oliveira, A. C. L., \& Miranda, G. J. (2015). Problemas percebidos no exercício da docência em contabilidade. Revista Contabilidade \& Finanças, 26(67), 93-105.

Barbosa, E. F., \& Moura, D. G. (2013). Metodologias ativas de aprendizagem na educação profissional e tecnológica. Boletim Técnico do Senac, 39(2), 48-67.

Bergmann, J., \& Sams, A. (2016). Sala de aula invertida: uma metodologia ativa de aprendizagem (A. C. da Cunha Serra, Trad.). Rio de Janeiro, RJ: LTC.

Biggs, J. (1999). What the student does: Teaching for enhanced learning. Higher Education Research \& Development, 18(1), 57-75.

Bordenave, J. E. (2002). Estratégias de ensino-aprendizagem $\left(23^{\text {th }}\right.$ ed.). Petropolis, RJ: Vozes.

Borges, T. S., \& Alencar, G. (2014). Metodologias ativas na promoção da formação crítica do estudante: o uso das metodologias ativas como recurso didático na formação crítica do estudante do ensino superior. Cairu em Revista, 3(4), 119-143.

Bordenave, J., \& Pereira, A. M. (2002). Estratégias de ensinoaprendizagem. Petrópolis, RJ: Vozes.

Breton, G. (1999). Some empirical evidence on the superiority of the problem-based learning (PBL) method. Accounting Education, 8(1), 1-12.

Camargo, C., \& Oliveira, M. F. (2017). Painel integrado: envolvendo todos individualmente. In: Leal, E. A., Miranda, G. J, Casa Nova, S. P. C. (Org.). Revolucionando a sala de aula: como envolver o estudante aplicando as técnicas de metodologias ativas de aprendizagem (Vol. 1, pp. 187-198). São Paulo, SP: Atlas.

Cardoso, S. (2017). Ciclo de carreira docente: o que dizem as pesquisas brasileiras? In Anais do IV Seminário Internacional de Representações Sociais, Subjetividade e Educação (42864297). Curitiba, PR/Brasil: PUC Paraná. Retrieved from http://educere.bruc.com.br/arquivo/pdf2017/24528_13853. pdf

Carenys, J., Moya, S., \& Perramon, J. (2017). Is it worth it to consider videogames in

accounting education? A comparison of a simulation and a videogame in attributes, motivation and learning outcomes. Revista de Contabilidad, 20(2), 118-130.

Castanho, M. E. L. M. (2003). Da discussão e do debate nasce a rebeldia. In I. P. A. Veiga (Org.), Técnicas de ensino: por que não? (Vol. 13, pp. 89-102). Campinas, SP: Papirus.

Colauto, R. D, Silva, O. L, Tonin, J. M. F., \& Martins, S. P. (2017). Filmes no processo de ensino e aprendizagem. In E. A. Leal, G. J. Miranda, S. P. C. Casa Nova (Org.), Revolucionando a sala de aula: como envolver o estudante aplicando as técnicas de metodologias ativas de aprendizagem (Vol. 1, pp. 125-139). São Paulo, SP: Atlas.
Comunelo, A. L., Espejo, M. M., Bernardes Voese, S., \& Lima, E. M. (2012). Programas de pós-graduação stricto sensu em contabilidade: sua contribuição na formação de professores e pesquisadores. Enfoque: Reflexão Contábil, 31(1), 7-26.

Cornachione, E. B., Jr. (2007). Tecnologia da educação e cursos de ciências contábeis: modelos colaborativos virtuais (Habilitation Thesis). Faculdade de Economia, Administração e Contabilidade, Universidade de São Paulo, São Paulo.

Retrieved from www.teses.usp.br.

Cruz, A. P. C. D., Quintana, A. C., Machado, D. G., Czarneski, F. R., \& Lucas, L. D. O. (2017). Quais atributos definem um bom professor? Percepção de alunos de cursos de ciências contábeis ofertados no Brasil e em Portugal. Revista Ambiente Contábil Universidade Federal do Rio Grande do Norte, 9(1), 163-184.

Curado, I. B. (2011). O método do caso. Revista Brasileira de Casos de Ensino em Administração, 4(1), 22-13.

Diehl, C. A., \& Souza, M. A. (2007). Formação, certificação e educação continuada: um estudo exploratório do profissional contábil sob a óptica das empresas head hunters. Revista Base (Administração e Contabilidade) da Unisinos, 4(3), 233-248.

Farias, C. M. L., \& de Carvalho, R. B. (2016). Ensino Superior: a geração Y e os processos de aprendizagem. Revista Espaço Acadêmico, 15(179), 37-43.

Ferreira, M. A. (2015). Determinantes do desempenho discente no Enade em cursos de ciências contábeis (Master's Dissertation). Faculdade de Ciências Contábeis, Universidade Federal de Uberlândia. Retrieved from http://repositorio.ufu.br/ handle/123456789/12620.

Folle, A., \& Nascimento, J. V. (2008). Estudos sobre desenvolvimento profissional: da escolha à ruptura da carreira docente. Journal of Physical Education, 19(4), 605-618.

Gainor, M., Bline, D., \& Zheng, X. (2014). Teaching internal control through active learning. Journal of Accounting Education, 32(2), 200-221.

Gil, A. C. (2006). Didática do ensino superior (18 $8^{\text {th }}$ ed.). São Paulo, SP: Atlas.

Graham, A. (2010). Como escrever e usar estudos de caso para ensino e aprendizagem no setor público. Escola Nacional de Administração Pública. Brasília, DF: Enap.

Guerra, C. J. O., \& Teixeira, A. J. C. (2016). Os impactos da adoção de metodologias ativas no desempenho dos discentes do curso de ciências contábeis de instituição de ensino superior mineira. Revista de Educação e Pesquisa em Contabilidade (REPeC), 10(4), 380-397.

Guimarães, M. L. F., Cittadin, A., Giassi, D., Guimarães, L. P., Filho, \& Bristot, V. M. (2016). Reflexos do uso de metodologias ativas no ensino da contabilidade de custos. ABCustos, 11(3), 60-84.

Hernandes, D. C. R., Peleias, I. R., \& Barbalho, V. F. (2006). O professor de contabilidade: habilidades e competências. In I. R. Peleias, Didática do ensino da contabilidade: aplicável a outros cursos superiores (pp. 61-119). São Paulo, SP: Saraiva.

Huberman, M. (2000). O ciclo de vida profissional dos professores. In A. Nóvoa (Org.), Vida de professores (Vol. 1, pp. 31-61). Lisboa: Porto Editora. 
Ikeda, A. A., Veludo-De-Oliveira, T. M., \& Campomar, M. C. (2005). A tipologia do método do caso em administração: usos e aplicações. Organizações \& Sociedade, 12(34), 141-159.

Isaia, S. D. A., \& Bolzan, D. P. V. (2010). Movimentos construtivos da docência/aprendizagem: tessituras formativas. Anais do XV ENDIPE (1-14). Belo Horizonte, MG/Brasil: UFMG.

Kachelmeier, S. J. (2002). In defense of accounting education. The CPA Journal, 72(10), 34.

Kane, L. (2004). Educators, learners and active learning methodologies. International Journal of Lifelong Education, 23(3), 275-286.

Koudela, I. D. (2011). A nova proposta de ensino do teatro. Sala Preta, 2, 233-239.

Leal, E. A., \& Borges, M. D. P. P. (2016). Estratégias de ensino aplicadas na área da contabilidade gerencial: um estudo com discentes do curso de ciências contábeis. Revista Ambiente Contábil, 8(2), 1.

Leal, E. A., Medeiros, C. R. O., \& Ferreira, L. V. (2017a). O uso do método do caso de ensino na educação na área de negócios. In E. A. Leal, G. J. Miranda, S. P. C. Casa Nova (Org.), Revolucionando a sala de aula: como envolver o estudante aplicando as técnicas de metodologias ativas de aprendizagem (Vol. 1, pp. 93-103). São Paulo, SP: Atlas.

Leal, E. A., Miranda, G. J, \& Casa Nova, S. P. C. (Org.). (2017b). Revolucionando a sala de aula: como envolver o estudante aplicando as técnicas de metodologias ativas de aprendizagem (1a ed.). São Paulo, SP: Atlas.

Leal, E. A., Miranda, G. J., \& Casa Nova, S. P. C. (2017c). Novas metodologias de ensino aplicadas à contabilidade: existe uma receita? Seção de Pôster apresentado no $11^{\circ}$ Encontro Catarinense dos Coordenadores e Professores de Ciências Contábeis, Florianópolis, SC.

Leal, D. T. B., \& Cornacchione, E., Jr. (2006). A aula expositiva no ensino da contabilidade. Contabilidade Vista \& Revista, 17(3), 91-113.

Lelic, S. (2001). Innovation: Fuel your imagination - Knowledge Management \& the art of storytelling. Seth Kahan. Retrieved from https://visionaryleadership.com/innovation-fuel-yourimagination-knowledge-management-the-art-of-storytelling.

Lopes, A. O. (2003). Aula expositiva: superando o tradicional. In I. P. A Veiga (Org.), Técnicas de ensino: por que não? (Vol. 13, pp. 35-113). Campinas, SP: Papirus.

Marques, A. V. C., Miranda, G. J., \& Mamede, S. P. N. (2017). Storytelling: aprendizado de longo prazo. In E. A. Leal, G. J. Miranda, S. P. C. Casa Nova (Org.), Revolucionando a sala de aula: como envolver o estudante aplicando as técnicas de metodologias ativas de aprendizagem (Vol. 1, pp. 169-184). São Paulo, SP: Atlas.

Masetto, M. T. (2003). Competência pedagógica do professor universitário. São Paulo, SP: Summus.

Matthiensen, A. (2011). Uso do coeficiente alfa de Cronbach em avaliações por questionários. Boa Vista, RR: Embrapa.

Mazzioni, S. (2013). As estratégias utilizadas no processo de ensino-aprendizagem: concepções de alunos e professores de ciências contábeis. Revista Eletrônica de Administração e Turismo-ReAT, 2(1), 93-109.
McDowall, T., Jackling, B., \& Natoli, R. (2015). Relationships between vocational interests and learning approaches to advance the quality of student learning in accounting. Accounting Education: An International Journal, 24(6), 498-513.

Medeiros, C. R. O., Miranda, G. J., \& Miranda, A. B. (2009). A arte no processo de ensino-aprendizagem e sua contribuição para a formação do contador: dramas e descobertas do estudanteartista. Revista Eletrônica de Administração (REAd), 16(2), 422-445.

Medeiros, C. R. O., Queiroz, Z. C. L. S. (2017). Encenando o ambiente de negócios: a representação teatral como técnica pedagógica. In E. A. Leal, G. J. Miranda, S. P. C. Casa Nova (Org.), Revolucionando a sala de aula: como envolver o estudante aplicando as técnicas de metodologias ativas de aprendizagem (Vol. 1, pp. 141-152). São Paulo, SP: Atlas.

Mendonça, J. R. C., \& Guimarães, F. P. (2008). Do quadro aos "quadros": o uso de filmes como recurso didático no ensino de administração. Cadernos EBAPE. Brasil, 6(special edition), $1-21$.

Menezes, M. A. D. (2009). Do método do caso ao case: a trajetória de uma ferramenta pedagógica. Educação e Pesquisa, 35(1), 129-143.

Miranda, G. J. (2011). Relações entre as qualificações do professor e o desempenho discente nos cursos de graduação em contabilidade no Brasil (Doctoral Thesis). Faculdade de Economia, Administração e Contabilidade, Universidade de São Paulo, São Paulo. Retrieved from www.teses.usp.br.

Moita, M. D. C. (2000). Percursos de formação e de transformação. In: A. S. Novoa, Vidas de professores. Porto, Portugal: Porto Editora.

Morán, J. (2015). Mudando a educação com metodologias ativas. In C. A. Souza, \& O. E. T. Morales (orgs.), Convergências midiáticas, educação e cidadania: aproximações jovens (Vol. 4, pps. 15-33). Ponta Grossa, PR: UEPG/PROEX.

Moura, M. F., Pereira, N. A, \& Souza, S. T. (2017). Debate: uma técnica de ensino voltada à pluralidade de pontos de vista. In E. A. Leal, G. J. Miranda, S. P. C. Casa Nova (Org.), Revolucionando a sala de aula: como envolver o estudante aplicando as técnicas de metodologias ativas de aprendizagem (Vol. 1, pp. 53-64). São Paulo, SP: Atlas.

Nganga, C. S. N., Botinha, R. A., Miranda, G. J., \& Leal, E. A. (2016). Mestres e doutores em contabilidade no Brasil: uma análise dos componentes pedagógicos de sua formação inicial. REICE: Revista Electrónica Iberoamericana sobre Calidad, Eficacia y Cambio en Educación, 14(1), 83-99.

Oliveira, A. S., \& Campos, L. C. (2017). Grupo de verbalização e grupo de observação. In E. A. Leal, G. J. Miranda, S. P. C. Casa Nova (Org.), Revolucionando a sala de aula: como envolver o estudante aplicando as técnicas de metodologias ativas de aprendizagem (Vol. 1, pp. 43-52). São Paulo, SP: Atlas.

Oliveira, J. D., Neto, \& Chioratto, V. H. (2017). A percepção crítica e reflexiva de graduandos sobre uma metodologia ativa na contabilidade. In Anais do 14th CONTECSI-International Conference on Information Systems and Technology Management. São Paulo, SP/Brasil: FEA USP.

Oliveira, J. D., Neto, Gomes, G. S. G., \& Titton, L. A. (2016). O uso da sala invertida, aliada a tecnologia, para promover 
aprendizagem ativa na contabilidade. In Anais do 14th CONTECSI-International Conference on Information Systems and Technology Management (pages). São Paulo, SP/Brasil: FEA USP. Retrieved from http://www.npt.com.br/wp-content/ uploads/2018/03/2016_VII.117_Contecsi_Gilvania.pdf.

Oliveira, V. S. D., \& Silva, R. F. (2012). Ser bacharel e professor: dilemas na formação de docentes para a educação profissional e ensino superior. Holos, 2, 193-205.

Perazo, A. N. C., Machado, D. G., da Cruz, A. P. C., \& Quintana, A. C. (2016). Perfil do docente de ciências contábeis: perspectiva de sua qualificação acadêmica, pedagógica e profissional. Revista Contabilidade e Controladoria, 2(8),49-65.

Perini, R., Fonseca, T. A., \& Gnap, C. I. (2018). Estratégias de metodologia ativa e a construção do profissional crítico e reflexivo. In Anais do IV Seminário Internacional Pessoa Adulta, Saúde e Educação (1-11). Porto Alegre, RS/Brasil: PUC Rio Grande do Sul. Retrieved from http://ebooks.pucrs. br/edipucrs/acessolivre/anais/sipase/assets/edicoes/2018/ arquivos/41.pdf.

Piolla, G. (2001). Vantagens e desvantagens do ensino baseado em problemas. UOL - Aprendiz. Retrieved from http://www2.uol. com.br/aprendiz/n_colunas/g_piolla/id270301.htm.

Rezende, M. G. D., \& Leal, E. A. (2013). Competências requeridas dos docentes do curso de ciências contábeis na percepção dos estudantes. Sociedade, Contabilidade e Gestão, 8(2), 145-160.

Ruff, M., Thibodeau, J. C., \& Bedard, J. C. (2009). A profession's response to a looming shortage: Closing the gap in the supply of accounting faculty. Journal of Accountancy, 207(3), 36.

Silva, R. H. A., \& Scapin, L. T. (2011). Utilização da avaliação formativa para a implementação da problematização como método ativo de ensino-aprendizagem. Estudos em Avaliação Educacional, 22(50), 537-522.
Soares, M. A., Botinha, R. A., Casa Nova, S. P. C., Soares, S. V., \& Bulaon, C. (2017). Aprendizagem baseada em problemas (APB) ou problem-based learning (PBL). In E. A. Leal, G. J. Miranda, \& S. P. C. Casa Nova (Org.), Revolucionando a sala de aula: como envolver o estudante aplicando as técnicas de metodologias ativas de aprendizagem (Vol. 1, pp. 105-123). São Paulo, SP: Atlas.

Souza, L. N. (2006). Role-play aplicado ao ensino da contabilidade: um estudo à luz dos estilos de aprendizagem e percepções discentes (Master's Dissertation). Faculdade de Economia, Administração e Contabilidade, Universidade de São Paulo, São Paulo. doi: 10.11606/D.12.2006.tde-15122006-091321

Stanley, T., \& Marsden, S. (2012). Problem-based learning: Does accounting education need it? Journal of Accounting Education, 30(3-4), 267-289.

Tavares, D. P., \& Ribeiro, L. O. M. (2016). Hipermídias no projeto e-Tec Idiomas: storytelling como tecnologia educacional. Revista de Informática Aplicada, 12(1), 96-109.

Valente, J. A. (2014). Blended learning and changes in higher education: the inverted classroom proposal. Educar em Revista, 4(special edition), 79-97.

Veiga, I. O. (2003). O seminário como técnica de ensino socializado. In I. P. A. Veiga (Org.), Técnicas de ensino: por que não? (Vol. 13, pp. 107-119). Campinas, SP: Papirus.

Villiers, R. (2010). The incorporation of soft skills into accounting curricula: Preparing accounting graduates for their unpredictable futures. Meditari Accountancy Research, 18(2), 1-22.

Weber, M. R., Finley, D. A., Crawford, A., \& Rivera, D., Jr. (2009). An exploratory study identifying soft skill competencies in entry-level managers. Tourism and Hospitality Research, 9(4), 353-361. 